\title{
Is daar vordering met die benutting van biologiese stikstofbinding?
}

Prosesse soos fotosintese en biologiese stikstofbinding (BS) gryp oor jare reeds die verbeelding van wetenskaplikes aan, nie net oor die rol wat hulle speel in die onderhouding van lewe op aarde nie, maar ook die uitdaging om die prosesse te manipuleer tot groter voordeel van die gemeenskap. Die hoë koste om in die stikstofbehoefte van onder andere die landbou te voorsien deur middel van die Haber-proses en, aan die anderkant, die grootskaalse uitskakeling van stikstofbesoedeling deur die selfregulerende BS-proses, dien as praktiese aansporingsmaatreëls om BS te bevorder.

Die gebrek aan skouspelagtige deurbrake met die benutting van die proses sedert vroeg in die eeu laat by baie landboukundiges die indruk dat BS-navorsing 'n statiese stadium bereik het. Die resultate van omvattende navorsing wêreldwyd veral sedert die begin van die sewentigerjare, weerspreek egter die siening. Trouens, 'n soliede basis van inligting is geskep wat te eniger tyd deurbrake met verreikende implikasies tot gevolg kan hê. Sonder om in besonderhede te verval wil ek 'n paar aspekte uitlig.

Dit is lank reeds bekend dat BS die kenmerk is van sekere mikro-organismes (prokariote) wat onder stikstofarm toestande en in die teenwoordigheid van molibdeen, die suurstoflabiele nitrogenase-ensiemsisteem (stikstofbindingsensiem) kan sintetiseer. Die katalisator van die reaksie is 'n molibdeen-ysterproteienkompleks. Onlangse navorsing het egter bevestig dat in die afwesigheid van molibdeen, sommige bakterieë vanadium as plaasvervanger in die proteïenkompleks kan gebruik. 'n Derde sisteem bestaan uit 'n proteienkompleks wat slegs yster bevat sonder enige molibdeen of vanadium.

'n Kenmerk van die stikstofbindingsreaksie is die hoë energievereiste daarvan. Om dit in die praktyk sovêr moontlik te beperk word stikstofbindende bakterieë wat ook oor 'n hidrogenase-ensiem beskik, nou by voorkeur geselekteer om te voorkom dat energie verspil word deur die vrystelling van waterstof vanaf protone wat in kompetisie met $\mathrm{N}$ deur nitrogenase gereduseer word.

Die nitrogenase-ensiem is reeds aangetoon by 'n groot verskeidenheid vrylewende bakterieë en blou-groen alge, asook by sisteme waar mikrobes in simbiose met plante stikstof bind. Die bekendse simbiotiese sisteme is die Rhizobium/Bradyrhizobium-peulgewaskombinasie en die simbiose tussen die aktinomiseet Frankia en sekere nie-peulgewasse. Stikstofbinding vind hier plaas onder gekontroleerde toestande in gespesialiseerde strukture (knoppe) wat op die plantwortels gevorm word. Onlangs is 'n nuwe simbiotiese sisteem ontdek waar die bakterie Azorhizobium stikstof bind in sowel wortel- as stamknoppe op o.a. sekere Sesbania, Neptunia en Aeschynomene spesies. Hierdie sisteem hou interessante moontlikhede in deurdat stamknoppe nie in direkte kontak met grondstikstof kom nie en dus kan funksioneer onder toestande waar hoë grondstikstof reeds die vorming en funksionering van wortelknoppe inhibeer. Die implikasie van stamknoppe by ekonomies belangrike peulgewasse is voor die hand liggend.
Die benuttingspotensiaal van BS vir die landbou is reeds in die vorige eeu besef en pogings om entstowwe te vervaardig vir die enting van peulgewasse dateer terug tot aan die begin van die huidige eeu. Nieteenstaande die ontdekking sedertdien van 'n groot verskeidenheid stikstofbindende sisteme waarvan sommige, soos byvoorbeeld die Azospirillum-grasassosiasie in die sewentigerjare, groot prominensie geniet het, bly die rhizobia-peulgewassimbiose die belangrikste vir die landbou. Die beperkte vordering met die benutting daarvan, ten spyte van navorsing wêreldwyd, reflekteer 'n onvermoë om die nodulasieproses in 'n komplekse grondomgewing sinvol te kan beheer en manipuleer. Pogings om hierdie probleem te oorkom het gelei tot intensiewe navorsing oor die meganisme van kompetisie vir knopvorming by rhizobia, die herkenningsmeganisme tussen bakterie en gasheerplant (spesifisiteit) waarmee reeds ver gevorder is, en 'n studie van die gene betrokke by die nodulasieproses. Met laasgenoemde is belangrike deurbrake gemaak ten opsigte van die interaksie tussen nodulasiegene in die bakterie (nod-gene) en spesifieke stowwe (flavone) wat deur die plant uitgeskei word. 'n Ander benadering wat reeds by sojabone vrugte afwerp, is om die onvermoë van entstofrasse om met gevestigde rhizobia in die grond te kompeteer, te omseil deur cultivars te teel wat nie met dominante, oneffektiewe rhizobia-populasies in die grond noduleer nie, maar slegs met 'n spesifieke entstofras.

Die snelle ontrafeling van genetiese en biochemiese aspekte van die nitrogenase-ensiem oor die afgelope twee dekades het verwagtinge geskep dat die oordraging na, en funksionering in plante van bakteriegene wat vir nitrogenase kodeer, binne afsienbare tyd aanleiding sou gee tot akkerbougewasse soos koring en rys wat in hulle eie stikstofbehoeftes voorsien. Optimisme is egter getemper namate dit duidelik geword het dat BS beheer word deur 'n komplekse kaskade geenmeganisme; die tans bekende 20 nif-gene wat 'n rol speel by die nitrogenase-ensiem is op hulle beurt onderhewig aan beheer deur die sogenaamde ntr-gene wat betrokke is by die stikstofassimilerende glutamiensintetaseensiem. Tesame hiermee bemoeilik eienskappe van die nitrogenase-ensiem self, soos sy suurstofgevoeligheid, die skep van 'n omgewing in die plant waar dit doeltreffend kan funksioneer.

Dit wil dus nou voorkom asof die doelwit om stikstofbindende plante te skep tydelik verskuif het na 'n strategie waar gepoog word om ekonomiese belangrike graangewasse (veral eensaadlobbiges) deur rhizobia te laat noduleer om sodoende stikstofbindende sisteme te skep soortgelyk aan die rhizobia-peulgewassimbiose. Die ontdekking in die vroeë sewentigerjare van 'n hoogs effektiewe stikstofbindende simbiose tussen rhizobia en die niepeulgewas Parasponia dui op 'n realistiese benadering in die verband - minstens op die kort termyn. Daar is reeds in geslaag om knopvorming te bewerkstellig by koring en rys na behandeling van die wortels met selwand- 
degraderende ensieme en enting met rhizobia. Geen stikstof is egter tot op die stadium deur die knoppe gebind nie. Die feit dat alle nie-peulgewasse wat tot dusver ondersoek is gene vir o.a. leghemoglobien bevat, dui daarop dat niepeulgewasse wel oor gene beskik analoog aan dié wat in peulgewasse by ' $n$ effektiewe stikstofbindende simbiose betrokke is.

Met die groter klem tans op plantgene betrokke by die simbiotiese proses, is die bestaan van wortelknopspesifieke proteïene, bekend as noduliene, aangetoon wat waarskynlik 'n sleutelrol speel by die regulering van infeksie en knopvorming. Verskeie noduliene is reeds geidentifiseer, maar min is nog bekend oor hulle funksies.

Suid-Afrika is een van die min lande wat reeds in dic vyftigerjare oor 'n peulgewasentstofbedryf beskik het. Dit het met rukke en stote ontwikkel om vanaf die middel sewentigerjare onder die beste gereken te kan word. Ten opsigte van gehalte en die verskeidenheid van entstowwe wat vervaardig word, is dit uitstaande. Plaaslike navorsing oor die laaste 20 jaar het ook beduidend bygedra tot die basiese kennis oor die benutting van die proses. Sou daarin geslaag word om nie-peulgewasse effektief met rhizobia te laat noduleer, behoort navorsing oor aspekte van die ekologie van rhizobia, entstofvervaardiging en die proses van nodulasie in grond wat reeds hier met die rhizobia-peulgewassimbiose uitsorteer is, ons in staat te stel om so 'n nuwe simbiotiese sisteem gou optimaal te kan benut.

Landboustatistiek van die afgelope twee of drie dekades en gegewens verskaf deur dr. V.D. Wassermann van die Navorsingsinstituut vir Plantbeskerming toon watter peulgewasse tot dusver 'n wesenlike invloed op BS in die SuidAfrikaanse landbou gehad het en wat ook die potensiaal vir uitbreiding het. Lusern, peulgewasweidings (in veral die winterreëngebied), lupiene en in 'n mindere mate akkerbone is hier ter sprake. Die verbouing van ander belangrike peulgewasse soos droëbone en erte het tot 'n groot mate gestagneer. Sojabone toon groei, maar die oppervlakte is steeds beperk.

Lusern is ongetwyfeld die belangrikste peulgewas en het waarskynlik die grootste potensiaal vir groei. Dit is ook die doeltreffendste ten opsigte van BS en bind gemiddeld meer as $300 \mathrm{~kg} \mathrm{~N} / \mathrm{ha} / \mathrm{jaar}$ onder besproeiing. Blykbaar het hooiproduksie oor die laaste 10 jaar gestabiliseer en dit skyn onwaarskynlik te wees dat die ongeveer 118000 ha besproeide lusern betekenisvol sal toeneem weens die kompetisie van ander gewasse. Droëlandlusern het egter groot potensiaal vir uitbreiding en die oppervlakkte van 468000 ha in 1981 kan na raming 100000 ha meer wees aan die einde van die eeu. Die Staat se grondomskakelingskema moedig ook die aanplanting van droëlandlusern aan en meer as 19000 ha was reeds in Julie 1990 onder die skema in die somerreëngebied gevestig.

Wcidingsrusoeste op peulgewasse gebaseer is belangrike stikstofverskaffers in die grond van die winterreëngebied en het in 1989 reeds 271543 ha beloop. Die oppervlakte onder beproeide gras-klawer-weidings het 'n addisionele 30000 ha beslaan, terwyl sowat 52000 ha onder lupiene was. Dit moet ook in ag geneem word dat 'n aansienlike gedeelte van die totale oppervlakte onder voergewasse in die gebied mengsels van wieke en kleingraan is. Aansoeke onder die grondomskakelingskema vir 'n verdere aanplanting van peulgewasse in die winterreëngebied beloop ook reeds meer as 70000 ha, waarvan 61000 vir lusern en eenjarige Medicago spp is.

Globaal gesien bestaan daar nie twyfel oor die potensiaal en wenslikheid om BS op groter skaal te benut nie. Navorsing het reeds die stadium bereik waar 'n deurbraak met verreikende gevolge vir die landbou moontlik is. Danksy kundigheid en die nodige infrastruktuur in hierdie stadium in Suid-Afrika, behoort nuwe ontwikkelinge geredelik toepassing in die landbou te vind. Met die geleidelike afname in die getal navorsers by die stikstofbindingseenheid van die Navorsingsinstituut vir Plantbeskerming, kan ons vermoëns in die opsig egter vorentoe ontoereikend word. Dit is myns insiens in landsbelang dat minstens 'n aanvullende navorsingsprogram op die gebied van BS, 'n volwaardige tuiste sal vind aan 'n plaaslike universiteitsdepartement.

B.W. STRYDOM 